\title{
Wisdom and Ethics - The Contribution of Sapiential Ethics
} for Old Testament Ethics

\author{
G Baumann ${ }^{1}$ \\ Universität Marburg \\ (University of Pretoria)
}

\begin{abstract}
Wisdom and Ethics - The Contribution of Sapiential Ethics for Old Testament Ethics
\end{abstract}

Old Testament sapiential literature is often described as "ethical literature", however, when concepts on Old Testament ethics are formulated, this literature is often overlooked. Furthermore, there are almost no monographs on the ethics of Old Testament wisdom. Could this perhaps be due to not only the claim that Old Testament wisdom thinking lacks divine revelation or reference to other Old Testament traditions (cf Nel 2002:435), but also to the opinion that there are no "ethics", but only "ethos" in this kind of literature? This article tries to show that "ethics" by definition can be found in Old Testament wisdom literature. Two recent German articles are introduced to the reader: Kaiser (1997) and Zimmermann (2002) reflect on the implicit and explicit ethics of Old Testament wisdom. These articles and other observations underscore the fact that the sapiential literature of the Old Testament contribute significantly to Old Testament ethics - and therein continues the efforts of authors like Nel (2002).

\section{A INTRODUCTION}

Studies on Old Testament wisdom literature often describe its character as "ethical” literature ${ }^{2}$. This character as ethical literature is ascribed predominantly to the book of Proverbs. In its admonitions and sayings it gives practical advice for many situations of daily life. In German scholarship one periodically finds the term "Sittlichkeit" which refers to proverbial wisdom. One century ago, Diettrich (1908) was first to see the fear of YHWH in Proverbs 1-9 as the

\footnotetext{
1 Dr Baumann is a Research Associate of the Department of Old Testament Studies at the University of Pretoria.

2 See eg Smend 1982:427: “Die Übergänge zwischen Sitte und Weisheit sind fließend."
} 
indispensable basis of ethics ${ }^{3}$. In 1997 Kaiser speaks of "basic morality" of Old Testament wisdom literature ${ }^{4}$. Also Zimmermann in 2002 refers to Old Testament wisdom literature as mirroring "first and foremost an outline of ethical behaviour, certain values and norms" literature - and primarily of the wisdom in the book of Proverbs - as "ethical literature". Nevertheless, proverbial or sapiential nature has not generally been the object of scholarly interest in ethics in the exegetical debate ${ }^{6}$. Up to 2002, there were hardly any monographs on the ethics of Old Testament wisdom ${ }^{7}$.

The mentioned disregard of sapiential ethics as such corresponds to the fact that scholars in the field of Old Testament ethics only rarely estimate wisdom literature and especially the book of Proverbs as the - or at least one - basis of Old Testament ethics ${ }^{8}$. Authors who try to systematise Old Testament ethics often focus or restrain themselves on Israel's confessions, the Ten Commandments, the different Law Codes, or prophetic texts. As an example, one could mention Otto's summarising articles ${ }^{9}$. Wisdom literature

3 “... die Jahwefurcht [wird] als unentbehrliches Fundament der Sittlichkeit erkannt". The latter means insight into life as the highest value and the duty of every human being towards God and other people (Diettrich 1908:492-497).

4 "Einfache Sittlichkeit" is the term used in the title of Kaiser (1997).

5 Zimmermann (2002:101): “... dass die weisheitlichen Lehrerzählungen und Sprüche in erster Linie einen Grundbestand sittlicher Verhaltensweisen, bestimmte Wertvorstellungen und Normen widerspiegeln".

6 I have already noticed this fact in my dissertation on personified Wisdom more than ten years ago: "Bemerkenswert ist m.E., daß der Aspekt der ethischen Unterweisung in der Forschung nicht eingehender zur Kenntnis genommen bzw. mit der theologischen Bedeutung der Weisheitsgestalt in Beziehung gesetzt wird, zumal ein wesentlicher Teil von Prov 1-9 aus ethischen Unterweisungen besteht” (Baumann 1996a:47).

7 "Monografische Untersuchungen zur Ethik in der Weisheit fehlen fast ganz" (Zimmermann 2002:100, note 6). He then lists the most important articles and paragraphs on this topic of the (then) last years, like, eg, Delkurt 1993.

8 For this fact and the reasons behind it; cf Nel (2002:435), who responds to this fact with an outline of the ontology and epistemology of Old Testament wisdom ethics.

9 Otto (1991a:608; 1991b; 1999:603-1606). In his monograph on Old Testament theological ethics (Otto 1994:152-174) the paragraph on (OT) wisdom ethics is much shorter that those on ethics in the Pentateuch, but it is 
seems to be easier to include in Old Testament ethics for those scholars who focus on certain topics and do not try to systematise the whole of Old Testament ethics ${ }^{10}$. Birch \& Rasmussen describe the exclusion not only of wisdom ethics, but of many other Old Testament ethical insights from theological systematisation: "Narrative accounts, historical events, wisdom sayings, parables, eschatological material, theological reflection, and liturgical material - all of these may yield as much ethical insight as passages that explicitly address ethical issues and sometimes with greater force" (Birch \& Rasmussen 1989:161).

So the question is, can or should Old Testament wisdom literature - and predominantly the book of Proverbs - be called "ethical literature"? If the answer is yes, the next question to ask is: What is its contribution to a notion of Old Testament ethics?

\section{B DEFINITIONS: “ETHICS” AND “WISDOM"}

For clarification of the topic, the definition of Zimmermann is helpful. He distinguishes "ethics" and "ethos". "Ethos" on the one hand mirrors - or is - the already mentioned collection of "ethical behaviour, certain values and norms" ${ }^{, 11}$. Ethos is the practical side of moral behaviour. "Ethics" on the other hand is a reflection on this practical ethos ${ }^{12}$. Similar definitions of "ethics" we find in other contributions on the topic ${ }^{13}$.

nevertheless thorough. However, wisdom ethics is - other than the ethics of other parts of the Old Testament - seen under the perspective of its "apories" (which are already approached in the two subtitles) and its failure: "Geht die Weisheit direkt von JHWH aus, so muß das unschuldige Leiden des Gerechten und der Mißerfolg weisheitlichen Ethos zu einer Anfrage an Gott und seine Gerechtigkeit werden” (Otto 1994:167). "Eine Vermittlung von Empirie und Gottesgedanken gelingt in der weisheitlichen Ethik unter Absehung von der Offenbarung Gottes in der Geschichte nicht” (Otto 1994:174).

10 See eg Janzen (1994), who in his "paradigmatic approach" also lists wisdom.

11 Zimmermann (2002:101): German quotation above (note 4).

12 Zimmermann (2002:101): “Die 'Ethik' hingegen ist gerade die methodische Reflexion dieses moralischen Verhaltens, ihr geht es um eine denkerische, systematische Durchdringung des Moralkodex.”

13 See eg Otto (1999:1603): “Die biblische Ethik reflektiert die Handlungsmaximen unter dem Gesichtspunkt des normativ Guten, fragt nach seiner Begründung und den Konsequenzen des guten Handelns.” 
Is there a reflection on Old Testament wisdom literature, including the book of Proverbs, in the Old Testament itself? Before we try to answer this question, we first have to clarify a second term which has a special meaning in scholarly literature but also does not originate in the Old Testament: the term “wisdom”. This does not mean that there is no word for wisdom: actually, there are several

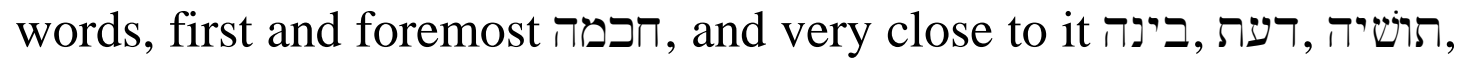
יראת יהוה or עצה and Baumann 1996:8691).

These terms, however, are not used for identifying wisdom in the sense of an intellectual phenomenon or of "wisdom thinking" which is more precisely the kind of wisdom which can be addressed as "(sapiential) ethics". Therefore, another definition is required. It is necessary to describe the phenomenon "wisdom" by listing its many aspects and functions in the Old Testament. Fohrer (1971:483) has described the phenomenon "wisdom" with the help of the following aspects of "sagacity or knowledge of man", or of human intelligence and knowledge:

(1) magic and manticism,

(2) skill and ability,

(3) cleverness, slyness and cunning,

(4) practical wisdom,

(5) culture,

(6) rules of conduct,

(7) ethical conduct,

(8) piety,

(9) academic wisdom,

(10) eschatological blessing and apocalyptical endowment (Fohrer 1971:483-489).

For the topic of ethics, not only "ethical conduct" in the narrow sense of the word (7) is relevant, but also other aspects: skill and ability (2), cleverness, slyness and cunning (3), practical wisdom, or common sense (4), culture, or education (5), rules of conduct (6), piety, or religious conduct (8), and academic wisdom, or the teaching of wisdom (9). In this perspective, proverbial "ethos" is a compilation of different aspects in the field of sapiential teaching.

According to our given definition of ethics, we now have to look for a reflection on or systematisation of the rules for human behaviour given in Old Testament wisdom. Does wisdom literature 
make an attempt to systematise all its aspects? Or, to put it differently: Is there ethics in the ethos of wisdom?

\section{IS THERE ETHICS IN THE ETHOS OF WISDOM?}

The answer is yes: There actually is a form of systematising ethical (and other) sapiential thought. This is the Wisdom figure or personified Wisdom in Proverbs 1-9. "Among the aspects mentioned above, the Wisdom figure in Proverbs 1-9 represents first of all skill and ability (2) as can be seen from the semantic parallels in Proverbs 8:12-14 and Exodus 31:3; 35:10. Prudence (3) and common sense (4) are also contained in the Wisdom Figure in Proverbs 8:12-14. 'Education' (5) occurs only in a small number of places in the Old Testament (Fohrer 1971:485). Together with the aspects of rules of behaviour (6), ethical (7) and religious conduct (8) it is present in Proverbs 1-9 as a subject which has to be studied. (...) Neither is Wisdom to be seen as a canon of didactic wisdom instruction (9). Such an aspect is created in Proverbs 1-9: After their completion these texts serve as a canon of wisdom facets which can be referred to from this point forward" (Baumann 1998:53).

Therefore, we could speak of personified Wisdom in Proverbs 1-9 not only as a personification of sapiential skills and all (positive) kinds of Wisdom. Personified Wisdom is also a form of Old Testament ethics in the sense, that it summarises and focuses these aspects.

Now that we answered the first question in a positive way, we can come to the next issue:

\section{CONTRIBUTION OF WISDOM TO AN UNDERSTAN- DING OF OLD TESTAMENT ETHICS: ITS EXPLICIT AND IMPLICIT ETHICS}

For answering this question let us go back to the already mentioned two recent articles of Kaiser and Zimmermann on the ethics of Old Testament wisdom literature. Kaiser sets his focus on the "basic morality" ("einfache Sittlichkeit”) of Old Testament wisdom. He finds it in

...righteousness and honesty of witnesses, incorruptibility of judges, honesty in trade, consideration of the weak, be they the poor, the widows, orphans or the foreigners, steady respect for the parents, abstaining from adultery and revenge, and besides the love for the friend also the unconditional solidarity with 
those who share blood and faith, and the foreigners living in the country

$$
\text { (Kaiser 199:1387) }^{14}
$$

The point that Kaiser makes is that all these aspects of "basic morality" can be not only found in Proverbs, but also in the Torah (Kaiser 1997:138). And like in the nearness of the Torah to YHWH, in post-exilic times the phenomenon "wisdom" is seen in closest contact with YHWH in personified Wisdom in Proverbs 8. So it is plausible and maybe inevitable that both Torah and Wisdom are seen in connection with each other in Deuteronomy 4:5-8. At a later stage in the 2nd century BCE, they are even equated in Ecclesiastics 1 and $24^{15}$. This could support the assumption that wisdom is giving a significant contribution to Old Testament ethics.

Whereas Kaiser focuses on the explicit ethics of Old Testament wisdom literature, Zimmermann (2002:101) looks for its implicit ethics. In this search, he systematises this ethics:

1. In the deed-consequence-nexus he finds a utilitarian approach, which means that it aims at the benefit for those who act. In the case where the benefit lies in the far future (for example, when a child is being educated, the "outcome" will only show some twenty years later), the utilitarian ethics can appear problematic (Zimmermann 2002:102-106).

2. Another type of ethics is the deontological one, which refers to higher principles, and can be separated into three lines (Zimmermann 2002:106-113):

a. The "naturalistic" type refers to external order as a basis for ethical behaviour.

14 Kaiser (1997:138): "Rechtlichkeit und Redlichkeit der Zeugen, Unbestechlichkeit der Richtenden, Ehrlichkeit im Handel, Rücksicht auf die Schwachen, seien es Arme, Witwen, Waisen oder Fremde, bleibende Achtung vor den Eltern, Enthaltung von Ehebruch, Verzicht auf Rache und neben der Liebe zum Freund die unbedingte Solidarität mit den Geblüt und Glauben teilenden Genossen und den im Lande weilenden Ausländern”; quoted without the nine [!] footnotes included in this passage which give biblical references in non-sapiential literature.

15 This has been widely acknowledged. See eg Marböck (1976:19; 1999:8196), Schimanowski (1985:56-58), or Baumann (1996b:139). 
b. The "ethics of virtue(s)" or "material ethics" is not so much grounded in the outcome of a deed, but refers to the values which fulfil a specific norm.

c. The "formal ethics" connects the ethical value of a deed to the actor's relationship towards a certain term or figure. In the case of wisdom literature, this could be personified Wisdom in Proverbs 1-9 or Sirach 24 (Zimmermann 2002:112).

In postexilic times, when the deed-consequence-nexus loses its plausibility, other ethical strategies are developed:

3. In Qohelet, hedonism stemming from Greek (Epicurean) origin is adapted. This ethics comes to the conclusion that only those things which lead to a good and happy life for a person are "good”, and vice versa (Zimmermann 2002:114-117).

4. At a late Old Testament stage, ethics becomes "theonomic"; it is stabilised by referring to YHWH: One should do certain things because YHWH has said so. Here again, we find a close connection between Torah and Wisdom. At this point, Zimmermann sees the emerging of two ethical principles which can only be grounded theonomically: the ethics of solidarity or charity ("Nächstenliebe"), represented in the term חסד, and the ethics of self-limitation ("Selbstbegrenzung"), which can be found in Job 28 in the hidden or inaccessible wisdom (Zimmermann 2002:117-121).

Not all of Zimmermann's consequences are plausible ${ }^{16}$, however, especially one of his thoughts seems to be convincing for the use of wisdom ethics for a discussion on Old Testament ethics (and, by the way, also for the discussion on the outcome of biblical ethics for today's ethical discussions), namely, the pluralistic approach of sapiential ethics. Sapiential ethics uses different ways of argumentation and different value systems side by side ${ }^{17}$.

16 For example, it might be debatable that Zimmermann's (2002:122) "theonomically" or theologically grounded ethics could solve some of the dilemmas in today's ethical discussions.

17 "Die implizite Ethik der Weisheit zeigt im Nebeneinander unterschiedlicher Argumentationsweisen und Wertesysteme eine dem heutigen Wertepluralismus vergleichbare Situation” (Zimmermann 2002:122). 
This is a point which also Kaiser makes: After a certain stage of "theologisation" of ethics in ascribing it to YHWH the earlier stages, the "basic morality" was not abandoned, but was maintained and even used in newly invented proverbs ${ }^{18}$.

Not only can this pluralistic approach of Old Testament sapiential ethics be found by systematising wisdom thinking, but also in the biblical text itself: Personified Wisdom in Proverbs 1-9 is the figure introducing the readers to the "basic morality" which we find in the older Proverbs (Prov 10-30*). Personified Wisdom functions not only as an introduction to these older Proverbs, but at the same time as a framework to connect many ethical strategies contained in the book of Proverbs (see eg Baumann 1996a:272-274).

\section{E CONCLUSIONS}

The contributions of sapiential or wisdom ethics to Old Testament ethics can be seen as the ethically pluralistic approach mentioned above; sapiential ethic uses and integrates different ethical strategies. interest:

Some further observations on sapiential ethics might be of

1. The universalistic approach of Old Testament wisdom is in line with Ancient Near Eastern and Egyptian wisdom literature. To consent with most of the ethical propositions, one does not have to believe in YHWH or worship YHWH (or other gods or goddesses). Seen from this perspective, sapiential ethics could and can be adapted to different contexts.

2. The fact that sapiential ethics is often "easy to adapt" helps to make it accessible for many people. One does not have to follow very difficult theological thoughts before being able to find the right solutions for basic problems.

3. The didactical character of wisdom and also of wisdom ethics has a special impact on the readers: In most cases, one is not called to do something in sapiential ethics. One is not forced into an ethical decision, as (especially in the deed-consequence-nexus) most of the admonitions leave the choice to the addressed person. Every

18 "Dabei läßt sich die These, daß der basale Charakter der Normen der einfachen Sittlichkeit auf allen Stufen der Entwicklung anerkannt blieb, allein schon mit der Beobachtung erhärten, daß nicht nur die jeweils älteren Sentenzen weiterhin tradiert, sondern auch weitere, der einfachen Sittlichkeit gemäße verschriftlicht oder gar neu gebildet worden sind” (Kaiser 1997:118). 
person decides on his or her own, if he or she wants to follow a certain advice - or ignore it. This encourages the ethical capability of the individual human being.

These observations should add further evidence to the fact that the sapiential wisdom of the Old Testament can contribute significantly not only to the issue of Old Testament's ethics, but also to contemporary ethical approaches.

\section{Consulted literature}

Baumann, G 1996a. Die Weisheitsgestalt in Proverbien 1-9. Traditionsgeschichtliche und theologische Studien. Tübingen: Mohr.

-, 1996b. "Zukunft feministischer Spiritualität” oder "Werbefigur des Patriarchats"? Die Bedeutung der Weisheitsgestalt in Prov 1-9 für die feministisch-theologische Diskussion, in Schottroff, L \& Wacker, M-Th (Hg), Von der Wurzel getragen. Christlich-feministische Exegese in Auseinandersetzung mit Antijudaismus. Leiden: Brill, 135-152.

-, 1998. A Figure with many Facets: The Literary and Theological Functions of Personified Wisdom in Proverbs 1-9, in Brenner A. \& Fontaine C R (eds), A Feminist Companion to the Bible, Second Series: Wisdom and Psalms, vol 2. Sheffield: Sheffield Academic Press, 44-78.

Birch, B C \& Rasmussen, L L 1989. Bible and Ethics in Christian Life, Minneapolis: Augsburg.

Delkurt, H 1993. Ethische Einsichten in der alttestamentlichen Spruchweisheit. Neukirchen-Vluyn: Neukirchener.

Diettrich, G 1908. Die theoretische Weisheit der Einleitung zum Buch der Sprüche, ihr spezifischer Inhalt und ihre Entstehung in ThStKr 81, 475512.

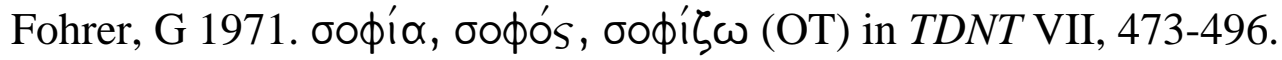

Janzen, W 1994. Old Testament Ethics: A Paradigmatic Approach, Louisville: Westminster John Knox.

Kaiser, O 1997. Einfache Sittlichkeit und theonome Ethik in der alttestamentlichen Weisheit in NZSThR 39, 115-139.

Marböck, J 1976. Gesetz und Weisheit. Zum Verständnis des Gesetzes bei Jesus Ben Sira in BZ 20, 1-21.

-, 1999. Weisheit im Wandel. Untersuchungen zur Weisheitstheologie bei Ben Sira. Berlin: de Gruyter.

Nel, P J 2002. The rhetorics of Wisdom's ethics in OTE 15, 435-452.

Otto, E 1991a. Ethik (AT) in NBL 1, 608-610.

-, 1991b. Forschungsgeschichte der Entwürfe einer Ethik im Alten Testament in $V u F$ 36, 3-37.

-, 1999. Ethik (AT) in RGG 2 (4 $4^{\text {th }}$ ed), 1603-1606. 
-, Theologische Ethik des Alten Testaments. Stuttgart: Kohlhammer.

Schimanowski, G 1985. Weisheit und Messias. Die jüdischen Voraussetzungen der urchristlichen Präexistenzchristologie. Tübingen: Mohr.

Smend, R 1982. Ethik (AT) in TRE X, 423-435.

Zimmermann, R 2002. Theologisierung der Ethik: Relikt oder Richtmaß? Die implizite Ethik der alttestamentlichen Weisheit und ihre Impulse für die gegenwärtige Diskussion in BThZ 19, 99-124. 